\title{
Do Not Prescribe Refills
}

National Cancer Institute

\section{Source}

National Cancer Institute. Do Not Prescribe Refills. NCI Thesaurus. Code C128510.

The prescriber must not prescribe refills of the drug. 